\title{
The use of electronic coupons in travel agencies: An exploratory study applied on Egyptian and US travel agents
}

\author{
Mona A.Elmoghazy
}

Hend M. Hamed

\begin{abstract}
This study explores the perception of travel agents towards using e-coupons. Two measurement scales were developed to assess and compare perceptions of travel agents that use e-coupons and those who do not in both Egypt and USA. The study examines the effect of positive outcomes of applying ecoupon strategy on travel agents' satisfaction and the impact of challenges facing travel agents on their future intentions. Furthermore, it explores the effect of objectives of using e-coupons on future intentions of travel agents not apply e-coupons. Significant differences between the two groups are investigated. The Study reveals that US travel agents have higher positive appreciation of e-coupons and lower perception of negative outcomes and challenges associated with using e-coupons than Egyptian travel agents. Several managerial and marketing implications and future research are also discussed.
\end{abstract}

\section{Keywords}

Electronic coupons (e-coupons), travel agencies, group-buying coupon websites, social couponing websites.

\section{Introduction}

For decades, industries have been aiming to provide customers with the right offer at the right time. This has become a reality through online marketing (Jones, 2012; Forrester Consulting, 2014).With the wide use of digital media by consumers, more companies are using e-marketing to reach their target markets. Studies indicated a preference for electronic coupons as an emarketing strategy among new generations. Thus, e-coupons are taking a significant role in the digital era (Smith, 2011; Zhao, Liu, Bi \& Law, 2014). This study will follow Chen \& Lu (2011)in referring to electronic coupons or e-coupons to those delivered through the internet.

E-coupons are an important marketing tool that influences consumer purchasing decisions (Forrester Consulting, 2014). Their importance will continue to grow as the improved internet and mobile technologies pave the way for e-coupons to become more targeted. The companies that preserve 


\section{The use of electronic coupons in travel agencies: An exploratory study applied on Egyptian and US travel agents}

transactional data and e-coupon history will be able to determine the right price and product for each consumer (Park \& Gretzel, 2011; Zhao et al., 2014).

Coupons have been widely studied by academics. the research has mainly focused on the e-coupon characteristics; the comparison between the use of ecoupons and traditional coupons, the effect of demographic characteristics on the usage of e-coupons, and the impact of using e-coupons for service recovery strategies in terms of maintaining repurchase intention and brand loyalty (Chiou- Wei\& Inman, 2008; Zhao et al., 2014).

Many websites currently distribute e-coupons for various tourism services such as restaurants, hotels and package holidays. E-coupons have a widespread and fast adoption in the tourism industry, which is obvious in the rise of coupon websites specializing in tourism such as weecation.com and deals.touristorama.com, as well as with the cooperation of major players such as groupon.com and expedia.com for the design and sale of coupons for tourism services (Sigala, 2013).

There is limited research that investigates the application of online coupons in tourism. Moreover, research on travel agencies' perception regarding applying e-coupons in their business does not exist. Certain studies have investigated the design and the implementation of online coupons discussing the face value and validity period of coupons to determine customer satisfaction and repurchase intention in online tourism and hospitality. Others have focused on the advantages and disadvantages of offering e-coupons by travel providers and tour operators through the daily deals websites, Groupon specifically (Sigala, 2013; Dev, Falk \& Stroock, 2011; Cheng \& Dogan, 2008).

This study aims at investigating the use of e-coupons in travel agencies as a marketing tool and the impact of that on their business. Specifically, the study aims to achieve the following objectives: (1) Explore the extent that travel agencies have reached in applying e-coupons. (2) Examining the significant differences between travel agencies in developed countries, such as the USA, and those in developing countries, like Egypt, in applying ecoupons in terms of services for which e-coupons are offered, the expected positive outcomes of using e-coupons, redemption and delivery methods, achievements and negative outcomes, challenges, satisfaction and future intentions.(3) Assess the effect of achievements of using e-coupons on travel agents' satisfaction. (4) Investigate the challenges confronting travel agents in using e-coupons and how they influence their future intentions. (5) Identify expected positive outcomes of using e-coupons that might influence future 
intentions of travel agents not using e-coupons. (6) Detect significant differences between travel agents using e-coupons and travel agents who do not in terms of expected positive outcomes and future intentions. (7) Propose solutions to overcome disadvantages and constraints facing travel agents in applying an e-coupon strategy.

The current paper first reviews the literature most relevant to the work by highlighting the definition of e-coupons and its emergence, then; it identifies the types of e-coupons and discusses the advantages and concerns associated with using e-coupons by travel agencies and it sheds light on the application of e-coupons in travel agencies in some countries. Next, methodology outlining the measures employed, data collection and analysis is detailed. Consequently, the results of the analysis are introduced and discussed. Finally, the implications and limitations are identified.

\section{Ltterature Review}

\subsection{E-coupon definition and background:}

Coupons, in general are promotional offers used by consumers for financial discount when purchasing a product. Tourism is one of the industries that often depend on coupons to promote its products and services. It has been initially used to influence tourists during a trip to buy unplanned excursions and optional services (Zhao et al., 2014; Park \& Gretzel, 2011).

The internet has led to the emergence of a new coupon generation called electronic coupons [e-coupons]. These coupons take the form of either a digital document that can be printed to be redeemed in a store or a promotional code that can be used for online purchases. E-coupons are distributed through websites; social media; search engines and e-mails. They can be printed on paper or scanned and redeemed directly from the customer's mobile device (Cheng \&Dogan, 2005; McKenzie \&Tullock, 2012; Kang, Hahn, Fortin, Hyun \& Eom, 2006; Mulpuru, 2014).

\subsection{Types of e-coupons}

E-coupons can be classified into various types according to the following aspects:

\subsubsection{Source}

This refers to the one issuing the coupon whether it is the supplier or the retailer (Blundo, Cimato \& De Bonis, 2005).An e-coupon issued by the supplier gives the consumer the advantage of using it at any couponaccepting store or website while the retailer's e-coupon can only be used at the retailer's stores, and on its website (Marketing Charts, 2012; Allen, 2014; Coupon Information Corporation, 2014). 


\section{The use of electronic coupons in travel agencies: An exploratory study applied on Egyptian and US travel agents}

In tourism, the supplier e-coupons are those issued by tourism suppliers such as airlines and hotels while the retailer's e-coupons are those issued on behalf of tour operators and travel agencies.

\subsubsection{Website type}

Until a few years ago, e- coupons had been dominated by third-party coupon aggregation sites. These sites include Coupon-providing websites or social couponing websites, which offer customers coupons for various stores and various products. A typical online coupon site requires users' registration. After that, users have free access to various daily coupons. Suppliers pay the online coupon site a certain fee each time a consumer redeems a coupon. Some famous examples of these coupon-providing sites are Coupon.com and CoolSavings (Allen, 2014; Santella \& Associates, 2013). Another type of third-party coupon aggregation sites is the group buying coupon websites that offer coupons with great deals for its subscribers, however, the deal is activated only when a minimum number of people, set previously by the retailer, are committed to buying. Companies wishing to promote their products through these websites offer online coupons at a major markdown and they also have to pay $50 \%$ of the coupon's face value to the coupon distributing website. One of the most famous groups buying coupon websites is "Groupon" (Allen, 2014; Lai \& Hsu, 2015; McKenzie \& Tullock, 2012; Yim, 2015).

Some group- buying and coupon- providing websites are specialized only in offering tourism services or a certain recreational service. OpenTable and SpotLight are examples that are specialized in offering coupons only related to dining (Kimes \& Dholakia, 2011).

Social networks and search engines started to build their own couponing sites to compete with the coupon- providing websites. "Living Social", a joint investment coupon-providing site between Amazon and Facebook, "Google Offers" is another couponing website that belongs to the search engine Google (Dev et al., 2011, p.14).

Suppliers and retailers currently offer coupons directly through their own websites. They want to offer their customers a better couponing experience to encourage them to frequently visit and stay on their websites rather than letting them go somewhere else to search for coupons. On the other hand, consumers are starting to search for coupons on the suppliers' and retailers' websites before searching the web for offers on other coupon websites (Allen, 2014). 


\subsubsection{Device}

E-coupons can be received from any device connected to the internet. It can be received on desktops or laptops to be printed and redeemed in store or to be used as a promotional code for an online purchase (Blundo et al., 2005; Reichhart, Pescher \& Spann, 2013;Yim, 2015).Customers also use their tablets and smartphonesfor having coupons which are redeemed eitheronline or in-store by scanning them on the device without needing to print them (EMarketer, 2014; Banerjee, Poddar, Yancey \& Mc Dowell, 2011; Banerjee \& Yancey, 2010;Yim, 2015).

\subsection{The advantages and concerns of using e-coupons by travel companies}

There is a big chance for retailers, like tour operators and travel agents, to master the digital coupon process. The easy provision and redemption of ecoupons accompanied by a balanced marketing plan can encourage customers to purchase and increase their spending at the company's location or on its website (Duncan \& Mulpuru-Kodali, 2014).

The advantages of using e-coupons by travel agencies match the benefits of using e-coupons in the retail business generally. This includes driving business, generating new users and increasing overall user spending as a result of attracting new customers and encouraging repurchase behavior in existing customers (Hoffman, Ketcham \& Taylor III, 1992; McKenzie \& Tullock, 2012; Business News Daily, 2011; Common Kindness, 2012). Besides, e-coupons are the most likely to influence consumer purchase decisions (Hoffman, et al., 1992; Chiou-Wei \& Inman, 2008). Studies show that $88 \%$ of visitors to coupon websites agreed that e-coupons close the deal for them when they are undecided on a purchase and $47 \%$ of consumers would try a new product when receiving an e-coupon (Forrester Consulting, 2014, p.5). Moreover, studies show that e-coupons can improve brand loyalty and reputation (McKenzie \& Tullock, 2012). 80\% of the consumers in the USA think that offering e-coupons on behalf of a certain company improves its brand image and increases customers' loyalty (Forrester Consulting, 2011; WhaleShark Media, 2011; Marketing Charts, 2014). In addition, e- coupons are easier to customize and personalize, hence, can target a certain group of consumers, such as those who have created an account or joined a mailing list, customize the coupon according to the profile the company have about them, personalize it, then distribute it via e-mails and messages on mobile devices to the right group of people. In this manner, e-coupons are delivered to the interested individuals that are actively searching for the product (Rampell, 2008; Hopkins, 2011; Hamlin, 2014; Eblin, 2015). Furthermore, e-coupons attract different groups to use them despite their different motivations.67\% of high-income households use e-coupons for buying the best-quality items and luxury services while $65 \%$ of low and middle-income 


\section{The use of electronic coupons in travel agencies: An exploratory study applied on Egyptian and US travel agents}

households are motivated more by savings (Marketing Chart, 2014; Zhao et al., 2014).

On the other hand, some studies show that there are certain benefits that travel institutions can specifically gain from using e-coupons. This involves using e-coupons by travel firms as an effective compensation strategy for enhancing service recovery. This occurs through offering a personalized ecoupon to the customer who is dissatisfied with a certain tourist service to show him that the travel company wants to make it up to him. This increases the degree of customer satisfaction, persuades repurchase intention and hence, assists service recovery (Zhao et al., 2014).

In the same vein, e-coupons can help in generating business in unstable conditions such as unstable political conditions when international tourism decreases, thus, the travel company can concentrate on offering e-coupons to encourage domestic tourism and fill up occupancy in low periods (Sigala, 2013).

Furthermore, e-coupons can be used by the travel companies as a strategic tool to expand its customers' base and confront the competition with online brokers and online tourist services and packages offered by travel providers (Cheng \&Dogan, 2008; Watters, 2014; McKenzie \& Tullock, 2012).

E-coupons also give the option of price differentiation since the travel company can offer the same product or service to consumers with various prices according to its objectives by offering e-coupons that differ in face value (Sigala, 2013; Cheng \& Dogan, 2008).

Finally, e-coupon customers spend more money in total than full-price paying customers as research has shownthat e-coupons increase the travel companies' revenues by attracting the customer to the discount of the ecoupon then influencing him to spend beyond the coupon's value on optional services (Sigala, 2013; Dholakia \& Tsabar, 2011).

Some travel providers offer e-coupons through coupon-providing websites and group-buying coupon websites to gain some of the benefits that these sites can provide to them. These benefits include exposure since these sites can help as a marketing tool for the tourism firms providing awareness to consumers about their product and service, especially, if the company is still new (Kimes \& Dholakia, 2011). It can also attract new customers to deal with the company as many of them would not try a new travel product or switch to another travel company without being offered a great deal through the social daily offers. A study indicated that $48 \%$ of the daily deal purchasers were new customers (Kimes \& Dholakia, 2011, p.7). These 
consumers can probably become returning customers who repeat their purchase at the regular price and recommend it to friends and family if they considered their first experience satisfactory (Dev et al., 2011).

In addition to benefiting from the customers' addiction to group-buying websites since some customers are always anxious to receive the daily deal. Hence, these sites can help in promoting and selling the travel agencies' tourist product and services (Sigala, 2013).

Studies indicate that the advantages of e-coupons outweigh the disadvantages. Many of the concerns about offering e-coupons, especially, through third-party coupon sites, are not substantial (Kimes \& Dholakia, 2011). The following section will present some of these concerns and how they can be overcome by applying a good e-coupon strategy.

The first concern is that e-coupons with big discounts offered by travel agencies, especially through group-buying websites, can lead to the dominance of deal seekers during high seasons and busy periods. Hence, they may take the place of the full-paying customers. In addition, increased customer volume resulting from redeeming e-coupons at the same time may negatively affect the service offered by the travel company. This challenge can be overcome by setting restrictions on when the e-coupon would be used. This can prevent receiving unexpected high volumes of customers at the same time or redeeming e-coupons in busy periods (Kimes \& Dholakia, 2011).

Second, e-coupons offered by travel companies, especially on the social couponing websites, may negatively affect the company's brand image. This can be true with over-couponing, thus, the solution for this is offering ecoupons at the right time when the company needs it, such as in low seasons or attracting new customers, to prevent brand image diminishing (Forrester Consulting, 2011; Georgieva, 2011).

The third concern involves poor customer match or the fear that e-coupons would only attract one-time bargain hunters who are influenced by the great discount and they rarely spendbeyond the deal's face value or return in the future. Other customers are those who fail to appreciate the tourist service and would spoil the experience for the other tourists. However, studies show that new customers who were influenced by an e-coupon in the first place most of the time switch to be frequent customers (Dev, et al., 2011; Business News Daily, 2011; Lai \& Hsu, 2015).

Last, e-coupons may annoy customers. This also can happen with overcouponing, sending the customer too many via e-mail or text messages may let him consider it as a spam. This can be avoided through better e-coupon strategy management; Sending e-coupons in certain occasions to encourage the recipient to take the purchase decision (Forrester Consulting, 2014; Georgieva, 2011). 


\section{The use of electronic coupons in travel agencies: An exploratory study applied on Egyptian and US travel agents}

\subsection{Applying e-coupons in travel agencies}

As mentioned before, research concerned with applying e-coupons in travel agencies does not exist. Thus, it is very hard to find in previous literature how e-coupons are utilized by travel agencies, specifically, in different countries. However, this section attempts to shed light on the available information in this regard.

Devet al. (2011) discussed how Groupon extended its business to include travel through its partnership with Expedia; the online travel agency in 2011 to provide daily travel deals in the U.K. through the new channel Groupon Getaways. Then, they proceeded with their case study explaining how an American tour operator in New York City aimed to increase the sales of package tours in slow periods by selling online coupons through Groupon. Sigala (2013) also handles e-coupons as those coupons offered electronically through group buying e-coupons and social couponing sites taking Groupon as an example. Zhao et al. (2014) explored e-coupons' role in online service recovery and in online travel reservation service. Dev et al.(2011) demonstrated the advantages and disadvantages that a tour operator can experience when offering customers e-coupons through group-buying websites such as Groupon. The biggest advantage happens when Groupon customers would occupy the empty seats during the slow periods and the low season while the main disadvantage was the conflict of interest between the tour operator and Groupon as Groupon's interest was to sell as many coupons as possible while the tour operator's was to gain a manageable number of discount guests who would spread the word of mouth to bring in additional business.

Zhao et al. (2014) results also revealed some advantages of using e-coupons by online travel companies in China such as reducing price sensitivity, attracting more customers to purchase, expanding sales rapidly, maintaining repeat purchase and promoting new products and above all that e-coupons can be regarded as an efficient way of compensation after online service failure when customers are more interested in compensation than in discount. In Egypt, there are two main local social e-couponing sites and three groupbuying e-coupon sites through which limited Egyptian travel agencies offer customers e-coupons. These sites are not specialized in travel; however, they provide e-coupons for various products and services among them tourism and hospitality services. Nine Egyptian travel agencies, such as MisrLelsyaha, Blue Sky and Travel Choice deal with those couponing sites. The pioneer Egyptian travel agencies in providing electronic coupons or deals are among the top travel agencies, leading the tourism business in Egypt (Asaeed, 2014). 
All the above-mentioned studies confirm the lack of academic research that deals with the application of e-coupons in travel agencies in general, in both developed and developing countries. In addition, none of the previous studies performed a comparison between developed and developing countries regarding the usage of e-coupons in any retail business, generally and in travel agencies specifically. Thus, the current research aims to fill this gap by exploring the perception of travel agencies concerning the application of ecoupons in their business through comparing the use of e-coupons by travel agencies in developed countries and those in developing countries. Developed countries are featured in the current study by the USA, the pioneer country in e-business, generally and in using online coupons in various fields specifically. Regarding e-tourism, it has started in the USA by the mid 90s. At present, digital travel sales are expected to reach $\$ 189.62$ Billion by the end of 2017, forming the largest share (30.9\%) of worldwide digital travel sales in 2017 (Hockenson, 2012; E-Marketer, 2017). Moreover, the USA is referred to as "the coupon nation" due to surpassing 11 developed countries with regard to the use of e-coupons by shoppers(PRNewswire, 2013) and more than half of US adult internet users redeeming e-coupons through any device for online and offline shopping (Emarketer, 2013).

Concerning the developing countries, Egypt presents them in this study. Egypt has entered the e-tourism field late and is still considered to be in the development stage in this area, however, due to the expansion and comfort with using technology and smart phones especially among the young population and the fast progress in online travel sales, particularly within the airline sector, e-tourism is currently expected to be growing faster in Egypt (Faraj, Fadnis, Hoffman, Strachan, Kaddoura \& Sileo, 2015; Euromonitor Inernational, 2016).

\section{Research Hypotheses}

Based on the brief assessment mentioned above and to achieve the aim of the current study of exploring the perception of travel agencies concerning the application of e-coupons in their business through comparing the use of ecoupons by travel agencies in developed countries, featured in USA, and those in developing countries, featured in Egypt, the following hypotheses are proposed:

H1: There are significant differences in e-coupons application between Egyptian and US travel agencies that employ e-coupons in their business.

H2: US travel agents are more satisfied with their achievements of applying e-coupons and have higher intentions to continue using e-coupons in the future than Egyptian travel agents. 


\section{The use of electronic coupons in travel agencies: An exploratory study applied on Egyptian and US travel agents}

H3: There are significant differences in e-coupons perception between Egyptian and US travel agencies that do not apply e-coupons.

H4: The non applying US travel agents have higher intentions to employ ecoupons in the future than the non applying Egyptian travel agents.

H5: The achievements of using e-coupons have a significant positive effect on the overall satisfaction for travel agents applying e-coupons

H6: Challenges confronting travel agents applying e-coupons have significant negative effects on their future intentions

H7: Expected positive outcomes of using e-coupons have significant positive effects on future intentions of travel agents that do not apply e-coupons.

H8: There are significant differences between travel agencies applying ecoupons and the non applying agencies regarding the expected positive outcomes of employing e-coupons in their business.

H9: There are significant differences between travel agents applying ecoupons and the non applyingtravel agents in relation to their future intentions.

\section{Research Methodology}

\subsection{Measurements}

To achieve the study objectives, two surveys were developed in this research, one for travel agents using e-coupons and the other for travel agents not using e-coupons, based on in-depth review of relevant literature pertaining to electronic coupons in tourism and travel industry(Zhao et al., 2014;Sigala, 2013; Park \& Gretzel, 2011; Kimes \& Dholakia, 2011; Dev et al., 2011; Banerjee \& Yancey, 2010).

To refine our measurements, first, three academic experts in electronic marketing were asked to verify the content validity of the preliminarily generated items. Second, four tourism experts were asked to indicate any of these measurement items needed to be refined. Third, a pretest was conducted with 9 travel agents in Egypt and 10 in the USA that use e-coupons for the first survey and 20 travel agents in Egypt and USA that do not use e-coupons for the second survey. Group-buying and daily deals websites were utilized to select travel agents that use e-coupons in both countries for the survey pretest. These websites are Groupon and Living Social for the US travel agents; Offerna and A1 Offers for the Egyptian travel agencies. After both groups of agents confirmed the validity of the scale, the 38 items of the measurement scale developed for agents using e-coupons, and the 13 items of the measurement scale developed for agents who do not use e-coupons were 
all representatives of the constructs of interest. All items were measured on a 5-point Likert scale. The first 16 items in the first survey ranged from never (1) to always (5), the rest of the items in the first survey and all the items in the second survey ranged from strongly disagree (1) to strongly agree (5).

The first survey was developed to measure the perception of travel agents who apply the e-coupon strategy in which the following seven constructs were measured:

1- Services for which e-coupons are offered which consist of seven items: We offer e-coupons for tour packages, flights, accommodation, ground transportation, dining, cruises, and excursions (Devet al., 2011; Sigala, 2013).

2- Delivery methods which consist of seven items: We use e-coupons through the company's website, targeted emails, social couponing websites, group buying coupon websites, partners' websites, social media, search engine couponing websites (Duncan \& Mulpuru-Kodali, 2014; Allen, 2014; Santella \& Associates, 2013).

3- Redemption methods, including two items: Purchasers usually redeem the company's e-coupons through printing them and purchasing at the company's location, Purchasers usually redeem the company's e-coupons through completing the purchase online (NCH Marketing Services, 2014; Duncan \& Mulpuru-Kodali, 2014).

4- Expected positive outcomes of using e-coupons encompassing six items: We use e-coupons to generate sales in slow periods, to decrease competition effect, to attract new customers, to attain current customers, to recover business in unstable periods, to increase revenues(NCH Marketing Services, 2009a; Dev et al., 2011).

5- Achievements of using e-coupons having five items: Using e-coupons increased our sales, increased our revenues, attracted new customers, enhanced our customers' loyalty, coupons increased our company's reputation (Dev et al., 2011; NCH Marketing Services, 2009b).

6- Negative outcomes of using e-coupons including five items: Using ecoupons decreased our revenues, caused to lose current customers, had negative effects on company's image, attracted the wrong kind of customers, attracted discount hunters only (Kimes \& Dholakia, 2011; Duncan \& Mulpuru-Kodali, 2014).

7-Challenges of using e-coupons encompassing four items: we face technical issues in applying e-coupons via the company's website, we face problems with the company's staff readiness in applying e-coupon strategy, poor social coupon website is one problem that keeps the company from offering ecoupons through them, there are few customers interested in electronic coupons (Dev et al., 2011). 


\section{The use of electronic coupons in travel agencies: An exploratory study applied on Egyptian and US travel agents}

Two more items were generated for this scale to measure the travel agents' overall satisfaction "overall we are satisfied with using e-coupons" and assess their future intention "we will keep using e-coupons in the future".

For travel agents who do not apply the e-coupon strategy, the survey instrument consists of the following three constructs:

1- Expected positive outcomes of using e-coupons in the future. This construct consists of six items: e-coupon strategy increases revenues, generates sales in slow periods, attracts new customers, attains current customers, recovers business in unstable periods, decreases competition (Dev et al., 2011; NCH Marketing Services, 2009a).

2-Potential negative outcomes of using e-coupons including three items: attracts the wrong customer, decreases revenues, e-coupons have negative effects on the company's image (Kimes \& Dholakia, 2011; Duncan \& Mulpuru-Kodali, 2014).

3- Potential challenges of using e-coupons, encompassing three items: we refuse to deal with coupon websites, the company's staff is still not ready for this job, the weakness of social couponing websites (Dev et al., 2011).

One more item was generated to measure the travel agents' future intention; "we will use e-coupons in the future".

Questions related to the demographic profile of respondents made the last part of both surveys.

\subsection{Data collection}

In this study, we conducted a series of self-administered surveys over a period of four months using a convenient sample of Egyptian and US travel agents from March 2015 to June 2015.

Some barriers were confronted in conducting the survey within the USA; it was first chosen to distribute the questionnaire on travel agencies in New York City, the core of business in the United States. The Questionnaire was distributed by email on 80 travel agencies located in NYC. Unfortunately, despite sending the survey to these travel agencies several times, there was no response from any of them. Instead, Cleveland in Ohio was chosen as an alternative to conducting the field study. Cleveland is a big city that encompasses a great deal of business generally and travel agencies, specifically. Thus, it serves as a good correspondent to Cairo in Egypt for accomplishing a comparison between the Egyptian travel agencies and the American travel agencies in applying e-coupons in their business. 
A brief description of the study was provided in the cover letter of the survey along with an explanation of e-coupons and its related aspects. The Survey was mainly written in English and it was translated into Arabic for the convenience of the Egyptian travel agencies

Yellow Pages Book, Google and Yahoo search engines were used to reach travel agents in Cleveland, $\mathrm{OH}$ and locate their contact information; mailing addresses, phone numbers and e-mail addresses.

A list of The Egyptian travel agencies brought from the Egypt's Travel Agencies Chamber was utilized to contact travel agencies in Cairo.

The questionnaires were delivered to the travel agents in person in both the USA and Egypt. The average time to collect questionnaires from agents was

7 days. Phone calls and e-mail messages were used to follow-up. The completed questionnaires were collected either by mail or in person.

A total of 300 questionnaires were distributed and 170were returned. After invalid questionnaires were excluded such as those with a high percent of incomplete answers or missing important questions, 156 responses were accepted for analysis, resulting in a valid response rate of 52\%; 84 were Egyptian travel agents and 72 were US travel agents. Based on the screening question in which agencies were asked if they use e-coupons, 47 agents were found to have used e-coupons, 18 of them were Egyptian travel agents and 29 were American travel agents, while 109agents have not used e-coupons before, 66 Egyptians and 43 Americans.

\subsection{Data analysis}

The data analysis consists of three stages. The first stage investigated the significant differences between Egyptian and US travel agents who apply ecoupons strategy in terms of services for which e-coupons are offered, delivery and redemption methods, expected positive outcomes of using ecoupons, achievements, negative outcomes, challenges, overall satisfaction and future intentions. An independent sample t-test was used to compare the two groups. It has also been identified whether significant differences existed between Egyptian and US travel agents who do not apply e-coupons in terms of, expected positive outcomes of using e-coupons, potential negative outcomes of using e-coupons, potential challenges, and future intentions. Again, independent sample t-test was used to determine if any significant differences existed between the two groups.

The second stage used a series of multiple regression analysis to model the extent to which different achievements of using e-coupons predict travel agents' overall satisfaction, and the extent to which challenges encountered while applying the e-coupon strategy predict future intentions. For travel agents who do not apply e-coupons, multiple regression analysis procedures 


\section{The use of electronic coupons in travel agencies: An exploratory study applied on Egyptian and US travel agents}

has been employed as well to examine how expected positive outcomes of using e-coupons might predict their future intentions.

The third stage examined whether any significant differences existed between agents applying e-coupon strategy and agents who do not apply e-coupon strategy in terms of expected positive outcomes of using e-coupons. The study examined also any significant differences found between the future intentions of both groups of agents'. The Multivariate Analysis of Variance (MANOVA) was used to assess any significant differences in the abovementioned variables between the two groups. The objective of this stage is to try to figure out any significant differences in the expected positive outcomes of using e-coupons between those who employ e-coupons and those who do not, and also to try to explore any significant differences in terms of future intentions; this will give an important indication of whether the experience of applying e-coupons is an important determinant that might affect future intentions.

\section{Results}

The internal consistency and reliability of the scale measuring travel agents perception of applying e-coupons were evaluated using Cronbach's alpha coefficients. Reliability tests are used to verify how the set of indicators hypothesized for each construct belong together (Nunnally, 1978). The reliability value of each construct is above 0.70 (Table $1 \& 2$ ) which is considered an acceptable value according to (DeVellis, 2003).

With regard to the demographic profiles of the 156 respondents, 84 (53.8\%) were Egyptian travel agents and $72(46.2 \%)$ were US travel agents. Among the 156 participants, $47(30.1 \%)$ were travel agents who are applying ecoupon strategy, 18 agents (38.3\%) were Egyptian travel agents and 29 $(61.7 \%)$ were US travel agents. While $109(69.9 \%)$ of the sample were travel agents who do not apply e-coupons, 66 (60.5\%) were Egyptian travel agents and $43(39.5 \%)$ were US travel agents.

\subsection{Differences in e-coupons perception for Egyptian and American travel agents applying e-coupon strategy}

In order to determine if there were significant differences between the Egyptian and US travel agents who apply e-coupon strategy regarding the 38 items, overall satisfaction and future intentions, an independent t-test was performed on the data set. Table (1) illustrates the comparison of Egyptian and American travel agents sample groups mean scores. Statistically 
significant differences were reported; for services for which e-coupons are offered, Egyptian travel agents had higher mean scores for offering ecoupons for flights $(\mathrm{P}<0.05$, Mean 3.8) and ground transportation $(\mathrm{P}<0.05$, Mean 3.7) compared to American travel agents (Mean: 2.4, 2.9) while American travel agents reported higher mean scores for offering e-coupons for dining $(\mathrm{P}<0.05$, Mean 3.9) and excursions $(\mathrm{P}<0.05$, Mean 4.4) compared to Egyptian travel agents (Mean: 3.1, 3.4). There were no significant differences concerning tour packages, accommodation, and cruises. For delivery methods, there were statistically significant differences in delivering e-coupons through targeted emails, social couponing websites, group buying coupon websites, and social media $(\mathrm{P}<0.05)$; for all of these methods, American travel agents had higher mean scores (Mean: 4.5, 5.0, 4.3, 4.6) compared to their Egyptian counterparts (Mean: 3.6, 2.9, 3.0, 3.7). With regard to redemption methods, a significant difference was found in redeeming e-coupons through completing the purchase online $(\mathrm{P}<0.05)$, as American travel agents reported higher mean score (Mean 4.7) than Egyptian travel agents (Mean 3.5). In terms of expected positive outcomes of applying e-coupons policy, American travel agents had higher appreciation of ecoupons (generate sales in slow periods: $(\mathrm{P}<0.05)$, Mean 4.6, decrease competition effect: $(\mathrm{P}<0.05)$, Mean 4.5, attract new customers: $(\mathrm{P}<0.05)$, Mean 4.8, attain current customers $(\mathrm{P}<0.05)$, Mean 4.9 and increase revenues: $(\mathrm{P}<0.05$, Mean 4.6) than Egyptian travel agents for all pre-mentioned expected positive outcomes of applying e-coupons (Mean: 3.9, 3.3, 3.7, 3.6, 3.5) except for recovering business in unstable periods as there was no significant difference found $(\mathrm{P}=0.988)$. With respect to theachievements of applying e-coupons strategy, as expected, American travel agents had significantly higher mean scores for all items of this dimension $((\mathrm{P}<0.05$, Mean: 4.7, 4.6, 4.6, 4.6, 4.3) than Egyptian travel agents (Mean: 3.6, 3.6, 3.7, $4.0,3.7)$. On the other hand, Egyptian travel agents demonstrated significantly higher mean scores concerning negative outcomes of using ecoupons $((\mathrm{P}<0.05$, Mean: 3.3, 3.2, 3.1, 2.5, 2.8) compared to American travel agents (Mean 1.3, 1.2, 1.1, 1.4, 1.5). Regarding challenges that travel agents face while using e-coupons, it seems that Egyptian travel agents face more challenges in this concern, as they had clear higher mean values $((\mathrm{P}<0.05$, Mean: 3.4, 2.9, 3.1, 2.7) compared to American travel agents (Mean: 1.6, $1.5,1.2,1.4)$. Obviously, these results influenced greatly both types of agents' overall satisfaction and future intentions, as Egyptian travel agents had clear lower mean scores: (Mean: $3.1 \&$ 3.00) compared to American travel agents (Mean: $4.7 \& 4.7$ ) for their overall satisfaction and intentions to use e-coupons in the near future. 
The use of electronic coupons in travel agencies: An exploratory study applied on Egyptian and US travel agents

Table (1) Differences in e-coupons perception for Egyptian and American travel agents applying e-coupon strategy

\begin{tabular}{|c|c|c|c|c|}
\hline & $\begin{array}{l}\text { Egyptian } \\
\text { Travel } \\
\text { agents }\end{array}$ & $\begin{array}{l}\text { American } \\
\text { Travel } \\
\text { agents }\end{array}$ & Sig. & Alpha \\
\hline $\begin{array}{l}\text { Services for which e-coupons } \\
\text { are offered }\end{array}$ & & & & .793 \\
\hline tour packages & 3.8 & 4.4 & 0.127 & \\
\hline flights & 3.8 & 2.4 & 0.000 & \\
\hline accommodation & 4.4 & 4.4 & 0.989 & \\
\hline ground transportation & 3.7 & 2.9 & 0.015 & \\
\hline dining & 3.1 & 3.9 & 0.033 & \\
\hline cruises & 3.6 & 3.7 & 0.678 & \\
\hline excursions & 3.4 & 4.4 & 0.001 & \\
\hline Delivery Methods & & & & .710 \\
\hline company's website & 4.2 & 3.8 & 0.288 & \\
\hline targeted e-mails & 3.6 & 4.5 & 0.007 & \\
\hline social couponing websites & 2.9 & 5.0 & 0.000 & \\
\hline group buying coupon websites & 3.0 & 4.3 & 0.000 & \\
\hline partners websites & 3.7 & 3.2 & 0.161 & \\
\hline social media & 3.7 & 4.6 & 0.013 & \\
\hline $\begin{array}{l}\text { search engine couponing } \\
\text { websites }\end{array}$ & 3.5 & 3.1 & 0.299 & \\
\hline Redemption Methods & & & & .700 \\
\hline $\begin{array}{l}\text { printing e-coupons and purchase } \\
\text { at the company's location }\end{array}$ & 3.6 & 3.6 & 0.969 & \\
\hline completing the purchase online & 3.5 & 4.7 & 0.001 & \\
\hline $\begin{array}{l}\text { Expected positive outcomes of } \\
\text { applying e-coupons policy }\end{array}$ & & & & .883 \\
\hline generate sales in slow periods & 3.9 & 4.6 & 0.033 & \\
\hline \multirow[t]{2}{*}{ decrease competition effect } & 3.3 & 4.5 & 0.001 & \\
\hline & & & 0.000 & \\
\hline attract new customers & 3.7 & 4.8 & & \\
\hline attain current customers & 3.6 & 4.9 & 0.001 & \\
\hline recover business in unstable & 3.8 & 3.8 & 0.988 & \\
\hline
\end{tabular}


periods

increase revenues

3.5

4.6

0.001

Achievements

3.6

3.6

3.7

4.0

3.7

increased our sales

4.7

.900

increased our revenues

4.6

0.000

created new customers

4.6

0.000

enhanced our customers' loyalty

4.6

0.000

increased our company's

4.3

0.003

0.022

reputation

Negative outcomes

decreased our revenues

3.3

1.3

.869

caused to lose current customers

3.2

1.2

0.000

had negative effects on

3.1

1.1

0.000

company's image

attracted the wrong kind of

2.5

1.4

0.000

customers

attracted discount hunters only

2.8

1.5

0.000

Challenges of applying ecoupon strategy

We face technical issues in applying e-coupons via the company's website problems with the company's

staff readiness in applying ecoupon strategy

Poor social-coupon websites is a

problem that keeps the company from offering e-coupons through them

few customers are interested in electronic coupons

Overall, we are satisfied with using e-coupons

We will keep using e-coupons $\quad 3.00$ 


\subsection{Differences in e-coupons perception for Egyptian and American travel agents not applying e-coupon strategy}

Independent t-tests examined the 13 items and future intention as can be seen in table (2). For expected positive outcomes of using e-coupons in the future, there were significant differences reported only for two items: attain current customers and decrease competition; American travel agents reported higher mean values. Regarding potential negative outcomes, there were significant differences for all items. Surprisingly, for all these items, Egyptian travel agents had higher mean scores.

For potential challenges perceived by both agents, there were significant differences reported in the analysis; The American travel agents had a higher mean value than the Egyptian agents for "Company's staff is not ready for this job", whereas Egyptian agents had a higher mean value than American agents for "Weakness of social couponing websites". There was no significant difference reported for both groups of agents' intentions to use ecoupons in the near future.

Table (2) Differences in e-coupons perception for Egyptian and American travel agents not applying e-coupon strategy

$\begin{array}{llll}\begin{array}{l}\text { Egyptian } \\ \text { travel agents }\end{array} & \begin{array}{l}\text { US travel } \\ \text { agents }\end{array} & \text { Sig. } & \text { Alpha } \\ & & \end{array}$

Expected positive

Increase revenues

3.7

3.8

0.553

Generate sales in slow 3.7

4.0

0.100

periods

Attract new customers $\quad 3.8$

$\begin{array}{ll}4.0 & 0.225\end{array}$

Attain current customers $\quad 3.6$

$4.0 \quad 0.046$

Recover business in 3.6

3.5

0.453

unstable periods

Decrease competition

3.4

4.1

0.000 


\section{continued}

Potential

negative

.819

outcomes

Attract the wrong kind of 3.0

2.1

0.000

customers

Decrease revenues

3.0

1.4

0.000

have negative effects on 3.0

1.6

0.000

company's image

Potential challenges of applying e-coupon policy

Refuse to deal with coupon 2.8

2.4

0.020

websites

Company's staff is not 2.8

3.4

0.008

ready for this job

Weakness of social 3.2

$2.4 \quad 0.000$

couponing websites

We intend to apply e- 3.5

0.165

coupon strategy in the

near future

\subsection{Effects of achievements of using e-coupons on overall satisfaction for travel agents applying e-coupon strategy}

A multiple regression analysis was performed to measure the independent effect of the 5items representing the achievements of using e-coupons on overall satisfaction (Table 3). The underlying assumption of linearity, normality, and variable independence were tested and met. The multiple regression analysis was significant and explained $43.3 \%$ of the variance $(\mathrm{F}=$ 6.257, $\mathrm{P}<0.05, \mathrm{R}^{2}=0.433$ ). Increasing company's sales had the largest standardized beta coefficient at 0.482 , meaning, for every one point increase in the company's sales, overall satisfaction increased $0.482(\mathrm{t}=2.00, \mathrm{P}<0.05)$. The standardized beta coefficient for increasing company's reputation was significant at $0.325(\mathrm{t}=2.193, \mathrm{P}<0.05)$. Other variables did not have a significant effect on overall satisfaction. 
Table (3) Regression coefficient (Achievements of using e-coupons \& overall satisfaction)

\begin{tabular}{llllll}
\hline Model Structure & $\begin{array}{l}\text { Standardized } \\
\text { coefficients (beta) }\end{array}$ & $\begin{array}{l}\text { t- } \\
\text { value }\end{array}$ & Sig. & $\mathbf{R}^{\mathbf{2}}$ & $\mathbf{F}$ \\
\hline $\begin{array}{l}\text { Achievements of using e- } \\
\text { coupons \& overall satisfaction }\end{array}$ & & & 0.000 & 0.433 & 6.257 \\
$\begin{array}{l}\text { Using e-coupons increased our } \\
\text { sales }\end{array}$ & 0.482 & & & & \\
$\begin{array}{l}\text { Using e-coupons increased our } \\
\text { revenues }\end{array}$ & -0.046 & 2.00 & 0.049 & & \\
$\begin{array}{l}\text { Using e-coupons created new } \\
\text { customers }\end{array}$ & 0.026 & - & 0.911 & \\
$\begin{array}{l}\text { Using e-coupons enhanced our } \\
\text { customers' loyalty }\end{array}$ & -0.048 & 0.113 & & \\
$\begin{array}{l}\text { Using e-coupons increased our } \\
\text { company's reputation }\end{array}$ & 0.325 & 0.071 & 0.944 & & \\
& & - & 0.797 & & \\
\hline
\end{tabular}

5.4 Effects of challenges encountered while employing e-coupons on the future intentions for the applying travel agents

A multiple regression analysis was used to assess the ability of previously mentioned challenges to predict travel agents' future intentions toward applying e-coupon strategy. Preliminary analyses were conducted as well, to ensure no violation of the assumption of normality, linearity, multi collinearity. The total variance explained by the model as a whole was $45 \%$, $\mathrm{F}=8.739, \mathrm{P}<0.001$, as illustrated in table (4). Three control measures were statistically significant; Poor social-coupons websites as a problem that keeps the company away from offering e-coupons had the highest beta value (beta= $-0.721, \mathrm{P}<0.05)$, the challenge concerning company's staff readiness in applying e-coupon strategy recorded a high beta value at $-0.596(\mathrm{P}<0.05)$. Technical challenges facing the company to apply e-coupons via the company's website was statistically significant as well with a high beta value at $-0.533(\mathrm{P}<0.05)$. 
Table (4) Regression coefficient (challenges encountered in applying ecoupons \& future intentions)

Model Structure

\section{Standardized} coefficients (beta)

$\begin{array}{llll}\text { t-value } & \text { Sig. } & \mathbf{R}^{2} & \text { F }\end{array}$

\begin{tabular}{|c|c|c|c|c|c|c|}
\hline $\begin{array}{l}\text { Challenges encountered in } \\
\text { applying e-coupons \& future } \\
\text { intentions }\end{array}$ & & & & 0.000 & 0.454 & 8.739 \\
\hline $\begin{array}{l}\text { we face technical issues in } \\
\text { applying e-coupons via the } \\
\text { company's website }\end{array}$ & -0.533 & & -2.214 & 0.032 & & \\
\hline $\begin{array}{l}\text { we face problems with the } \\
\text { company's staff readiness in } \\
\text { applying e-coupon strategy }\end{array}$ & & -0.596 & -2.284 & 0.028 & & \\
\hline $\begin{array}{l}\text { Poor social-coupons websites is a } \\
\text { problem the keeps the company } \\
\text { from offering e-coupons }\end{array}$ & -0.721 & & -3.731 & 0.001 & & \\
\hline $\begin{array}{l}\text { There are few customers interested } \\
\text { in electronic coupons }\end{array}$ & 0.191 & & 0.875 & 0.387 & & \\
\hline
\end{tabular}

\subsection{The effects of expected positive outcomesof using e-coupons on future intentions for the non applying travel agents}

To explore the effect of the expected positive outcomes of using e-coupons according to the perspectives of travel agents who do not use e-coupons on their future intentions, we estimated multiple regression by using objective variables as control variables. Table (5) reports the results. The total variance explained by the model was $62 \%, \mathrm{~F}=28.297, \mathrm{P}<0.05$. Increase revenues had the highest beta value (beta $=0.361, \mathrm{P}<0.05$ ), generate sales during slow periods recorded a high beta value as well at $0.300(\mathrm{P}<0.05)$, these two expected positive outcomes of using e-coupons were the only variables with significant effect on future intention. 
The use of electronic coupons in travel agencies: An exploratory study applied on Egyptian and US travel agents

Table (5) Regression coefficient (expected positive outcomes of using ecoupons \& future intentions) for non-users travel agents)

\begin{tabular}{llllll}
\hline Model Structure & $\begin{array}{l}\text { Standardized } \\
\text { coefficients (beta) }\end{array}$ & $\begin{array}{l}\text { t- } \\
\text { value }\end{array}$ & Sig. & $\mathbf{R}^{2}$ & $\mathbf{F}$ \\
\hline $\begin{array}{l}\text { Expected positive outcomes of } \\
\text { using e-coupons \& future }\end{array}$ & & & 0.000 & 0.625 & 28.297 \\
$\begin{array}{l}\text { intentions } \\
\text { increase revenues }\end{array}$ & 0.361 & & & & \\
$\begin{array}{l}\text { generate sales in slow periods } \\
\text { attract new customers }\end{array}$ & 0.300 & 3.842 & 0.000 & & \\
attain current customers & 0.173 & 3.360 & 0.001 & & \\
recover business in unstable & 0.163 & 1.855 & 0.066 & & \\
$\begin{array}{l}\text { periods } \\
\text { decrease competition }\end{array}$ & 0.009 & 1.922 & 0.057 & & \\
& -0.126 & 0.116 & 0.908 & & \\
& & - & 0.140 & & \\
\hline
\end{tabular}

5.6 Comparison of expected positive outcomes of using e-coupons and future intentions between travel agents applying e-coupons strategy and travel agents not applying e-coupons

A Multivariate Analysis of Variance (MANOVA) was performed to assess any statistical differences in expected positive outcomes of using e-coupons and future intentions between the two segments. The seven items associated with expected positive outcomes of using e-coupons and future intentions were used as dependent variables, and the type of travel agent (applying or not applying e-coupons) was used as the independent variable in the analysis. Preliminary assumption testing was conducted to check for normality, linearity, univariate and multi collinearity with no serious violations noted. Significant differences were found between the two segments on the combined dependent variables, $(\mathrm{F}(7,148)=2.218, P=0.036$; Wilks' Lambda= 0.905 . When the results for the dependent variables were considered separately, the differences to reach statistical significance, using a Bonferroni adjusted alpha level of 0.007 , were: generate sales in slow periods, attract new customers, attain current customers and increase revenues as shown in table (6). An inspection of the Mean scores indicated that travel agents applying e-coupon strategy reported the slightly higher level of expected positive outcomes of using e-coupons and future intentions. However, no significant differences were obtained in this concern. 
Table (6)Tests of Between-Subjects Effects, estimated marginal Means

\begin{tabular}{|c|c|c|c|c|c|c|c|}
\hline $\begin{array}{l}\text { Dependent } \\
\text { Variable }\end{array}$ & $\begin{array}{l}\text { Apply e- } \\
\text { coupons } \\
\text { strategy } \\
(\mathbf{M} / \mathrm{SD})\end{array}$ & $\begin{array}{l}\text { Type III } \\
\text { Sum of } \\
\text { Squares }\end{array}$ & df & $\begin{array}{l}\text { Mean } \\
\text { Square }\end{array}$ & $\mathbf{F}$ & Sig. & $\begin{array}{l}\text { Patial } \\
\text { Eta } \\
\text { Squared }\end{array}$ \\
\hline $\begin{array}{l}\text { generate sales in } \\
\text { slow periods }\end{array}$ & $\begin{array}{l}\text { Yes } \\
4.383 / 0.147 \\
\text { No } \\
3.844 / 0.096\end{array}$ & 9.539 & 1 & 9.539 & 9.449 & 0.002 & 0.058 \\
\hline $\begin{array}{l}\text { decrease } \\
\text { competition } \\
\text { effect }\end{array}$ & $\begin{array}{l}\text { Yes } \\
4.106 / 0.158 \\
\text { No } \\
3.725 / 0.104\end{array}$ & 4.782 & 1 & 4.782 & 4.087 & 0.045 & 0.026 \\
\hline $\begin{array}{l}\text { attract new } \\
\text { customers }\end{array}$ & $\begin{array}{l}\text { Yes } \\
4.404 / 0.126 \\
\text { No } \\
3.917 / 0.083\end{array}$ & 7.783 & 1 & 7.783 & 10.370 & 0.002 & 0.063 \\
\hline $\begin{array}{l}\text { attain current } \\
\text { customers }\end{array}$ & $\begin{array}{l}\text { Yes } \\
4.426 / 0.146 \\
\text { No } \\
3.817 / 0.096\end{array}$ & 12.180 & 1 & 12.180 & 12.195 & 0.001 & 0.073 \\
\hline $\begin{array}{l}\text { recover business } \\
\text { in unstable } \\
\text { periods }\end{array}$ & $\begin{array}{l}\text { Yes } \\
3.830 / 0.143 \\
\text { No } \\
3.587 / 0.094\end{array}$ & 1.933 & 1 & 1.933 & 2.025 & 0.157 & 0.013 \\
\hline $\begin{array}{l}\text { increase } \\
\text { revenues }\end{array}$ & $\begin{array}{l}\text { Yes } \\
4.234 / 0.137 \\
\text { No } \\
3.771 / 0.090\end{array}$ & 7.052 & 1 & 7.052 & 8.004 & 0.005 & 0.049 \\
\hline $\begin{array}{l}\text { we will apply } \\
\text { e-coupons with } \\
\text { customers in the } \\
\text { future }\end{array}$ & $\begin{array}{l}\text { Yes } \\
4.064 / 0.145 \\
\text { No } \\
3.624 / 0.095\end{array}$ & 6.357 & 1 & 6.357 & 6.424 & 0.012 & 0.040 \\
\hline
\end{tabular}

\section{Discussion}

The results of the study reveal that there are significant differences between Egyptian and US travel agents who are using e-coupons in terms of services for which e-coupons are offered; Egyptian travel agents use e-coupons more for flights and ground transportation, while US travel agents offer e-coupons more for dining and excursions. However, no statistical differences were found concerning tour packages, accommodation, and cruises. The study reveals as well, that US travel agents have more experience with e-coupon delivery methods as significant differences were found in all delivery methods, except for delivery through the company's website and through a 


\section{The use of electronic coupons in travel agencies: An exploratory study applied on Egyptian and US travel agents}

partner's website. For e-coupon redemption methods, US travel agents' customers have higher rates of redeeming e-coupons through completing the purchase online when compared to the rate of using this method by Egyptian travel agents; a reasonable finding when more convenience and familiarity with online payment methods and e-commerce on behalf of the American customer is considered. Concerning expected positive outcomes of using ecoupons, US travel agents have a higher perception of all expected positive outcomes a travel agency may seek to achieve through using e-coupons except for the item recovery business in unstable periods as there was no significant difference in this regard. Not surprisingly, results indicate that US travel agents reported more achievements from using e-coupons, while Egyptian travel agents put a great emphasis on negative outcomes and challenges related to using e-coupons, this might be due to lack of experience of how to best benefit from this tool. According to the pre-mentioned findings, H1 was partially supported. Obviously, these results influenced greatly both groups of agents' overall satisfaction and future intentions, as there are apparent significant differences between the two groups in this concern which support $\mathrm{H} 2$. These results reveal the great difference in the perception of e-coupons between travel agents applying e-coupon strategy depending on the country in which the travel agent operates. Since the USA is more acquainted with using e-coupons; it could be argued that the more experienced the country (in which the agent operates) with using e-coupons, the more advanced it will be in gaining more benefits from utilizing it in business. Given that American consumers are more familiar with technology, e-commerce and using e-coupons than Egyptian consumers, one can claim that heavy technology users among e-coupons' customers affect greatly the success of achieving the benefits of using e-coupons, this result is consistent with what Chiou and Inman (2008) mentioned in their study that the main segments using electronic coupons are more exposed to recent technologies.

On the other hand, the results of the present study reported significant differences between travel agents who do not use e-coupons in both Egypt and in the USA, in terms of expected positive outcomes of using e-coupons for the following: attain current customers and decrease competition; as US travel agents have a higher appreciation of these two expected positive outcomes compared with their Egyptian counterparts. This reflects the intense competition among travel agents in the USA, in using e-coupons to attain their customers from switching to competitors. This result is consistent with what Zhao et al. (2014) mentioned in their study, that it is crucial for 
tourism businesses to retain long-term relationships with customers to obtain competitive advantage.

The findings reveal that the Egyptian travel agents have a higher perception of the potential negative outcomes. The results indicated as well that the US travel agents have a higher perception of the potential challenge concerning staff readiness to undertake this job while Egyptian travel agents have higher consideration for the potential challenge concerning weaknesses of the social couponing websites According to the previous results, H3 was partially verified. Hypothesis $\mathrm{H} 4$ is not verified by the study results as there is no significant difference found between the two groups concerning their future intentions.

For travel agents using e-coupons, the current study agree with Sigala (2013) that increasing the company's sales and increasing company's reputation have a significant effect as well as the achievements of using e-coupons on travel agents' overall satisfaction. Therefore, hypothesis H5was partially verified since not all items representing achievements have significant positive effects on overall satisfaction. When assessing the challenges that travel agents using e-coupons face and their influence on agents' future intentions, the study indicates that poor social couponing websites, the company's staff readiness and technical challenges have a significant negative impact on their future intentions which partially support hypothesis H6.On the other hand, the study attempted to figure out which expected positive outcomes might affect the future intentions of travel agents who do not apply e-coupon strategy; results indicate that increase revenue and generating sales in slow periods were the only two expected positive outcomes of using e-coupons that significantly affect their future intentions which partially verified hypothesis $\mathrm{H} 7$.

Analysis reveals that significant differences were found between travel agents applying e-coupon strategy and those who do not, with reference to expected positive outcomes of using e-coupons; travel agents using e-coupons reported slightly higher perception of generating sales in slow periods, attracting new customers, attaining current customers and increasing revenues than travel agents who do not use e-coupons. Accordingly, hypothesis H8 was partially verified. This result indicates that the experience of using e-coupons could be a considerable determinant of perceiving positive outcomes of implementing this promotional tool and inducing agents to use e-coupons in the future.

Finally, there was no significant difference between the two groups concerning future intention of using e-coupons, hence, the final hypothesis H9 was rejected.

\section{Conclusion}

Despite their widespread use, e-coupons have been rarely studied in the context of the retail travel industry. Compared with very few previous studies 


\section{The use of electronic coupons in travel agencies: An exploratory study applied on Egyptian and US travel agents}

which focused on e-coupons in the travel industry from a consumer's perspective (Banerjee \& Yancey, 2010; Kimes \& Dholakia, 2011; Park \& Gretzel, 2011; Sigala, 2013;Zhaoet al., 2014) the present study is considered the first study examining the effect of using e-coupons from a travel agent's perspective. It contributes to marketing and tourism literature by discussing different dimensions associated with using e-coupons in travel agencies.

One of the most important theoretical contributions of the present study lies in integrating different unique structures related to using e-coupons in the travel market to understand the relative importance of e-coupons in the retail travel environment.

This research generates insights for managers and marketers to understand the most salient aspects of e-coupons' usage in travel agencies to address what drives and what inhibits adopting e-coupons strategy. By understanding how travel agents evaluate their experiences with e-coupons, marketers and managers can carry out necessary adaptations to their offerings to best meet and enhance customers' needs. The proposed measures for understanding both types of agents' perceptions toward applying e-coupons strategy can provide a practical tool for managers to assess positive and negative outcomes of using e-coupons, and challenges according to both types of agents' points of view.

Furthermore, the current study identifies the positive outcomes generated from applying e-coupon strategy as stated by agents using e-coupons in their business and the effect of these outcomes on the travel agents' satisfaction. The study identifies as well the actual challenges that confront travel agents using e-coupons and their impact on the future intentions of these agents. Given the importance of assessing the potential of using e-coupons in the future, the study illustrates key expected positive outcomes that influence the intentions of agents who are not currently using e-coupons.

The study reveals that the unfamiliarity with e-coupons by travel agents can lead to being confused by the different expected positive outcomes and potential negative outcomes and potential challenges related to using ecoupons. Thus, managers and marketers should attempt to formulate an effective layout and information strategies to enhance their knowledge and awareness and assess the effectiveness of adopting e-coupon strategy.

As for the disadvantages and challenges associated with using e-coupons reported in literature and in the study results, travel agents need to consider several solutions to overcome these disadvantages and challenges; for instance, a travel agency can overcome the challenges that might face applying its e-coupon strategy by a well-designed e-coupon with a good face 
value and clear redemption restrictions and good strategic management that would lead to the benefit of both the travel agency and the customer. The travel agency can set restrictions on the e-coupon that can help in limiting the e-coupon sales to one per person and controlling the redemption period, preventing multi-coupon purchases and redeeming coupons in undesired or busy times. Another important solution is providing e-coupons directly to the recipient through the agency's own website, email alerts and mobile applications rather than depending mainly on social couponing or group buying coupon websites. This gives the agency the chance to have full control on the minimum and maximum number of e-coupons offered on its behalf and fully manage its e-coupon strategy without any conflict between its aspirations and other parties' objectives.

The travel agency can customize and personalize e-coupons according to customers' profiles, targeting customers with special e-coupons and offers that meet their needs and enhance the chance of their purchase. Furthermore, the agency can send customers e-coupons on different occasions according to the data in their profile, birthdays, anniversaries and others, or send them ecoupons as a gift for being a loyal customer; besides encouraging the customer on the website to register in order to receive an e-coupon with a big discount for being a first-time customer. In addition, online customers' reviews posted on the travel agency's website can help the travel agency to collect useful information and valuable feedback about its deals and tourist services in order to further improve them.

Travel agencies could also reduce the costs of applying e-coupons by limiting the business with social couponing websites, hence, limiting the percent taken by them on each transaction.

Finally, travel agents should focus more on introducing their employees to the new technological, marketing and sales tools through workshops and training programs to better serve their customers.

\section{LIMITATIONS AND FUTURE RESEARCH}

The present study emphasizes the different aspects related to applying ecoupon strategy in travel agencies. However, it has several limitations that need to be addressed. First, the data were collected from Cairo and Cleveland only, therefore, generalizing the study results to other travel agents in different regions may be inappropriate. Second, the questionnaire used a convenience sampling method, which put another limitation to generalizing the results of the current study. The sample size is relatively small, future research should consider using larger samples to be able to generalize the results to a broader context. With time, the challenges construct examined in this research requires further investigation to assess emerging challenges with the increased use of e-coupons among travel agents. Modeling the 


\section{The use of electronic coupons in travel agencies: An exploratory study applied on Egyptian and US travel agents}

relationship between the positive and negative outcomes of applying ecoupon strategy requires further investigation as this will assist managers to develop distinct strategies and programs when deciding to use e-coupons.

Obviously, more comparative studies among travel agents within different countries with different levels of advancement in using e-coupons could produce interesting results. Future research should expand the existing constructs to examine the effect of using e-coupons by the travel agent on other dimensions such as new product trial, targeting the niche tourism market, brand awareness and repeated purchase.

\section{REFERENCES}

Allen, W. (2014). Four keys to making digital coupons more relevant. Digital solutions, Shopper Technology Institute. Retrieved from:www.couponfactory.com. [Accessed on: 2 February 2015].

Alsaeed, R.A. (2014).The most popular websites for promotion and discounts in Egypt for e-shoppers. Retrieved from:http://digital.ahram.org.eg/articles.aspx?Serial=1682467\&eid=13859. [Accessed on: 30 December 2014].

Banerjee, S. \& Yancey S. (2010). Enhancing mobile coupon redemption in fast food campaigns. Journal of Research in Interactive Marketing, 4 (2), pp. 97 - 110.

Banerjee, S., Poddar A., Yancey, S. and Mc Dowell, D. (2011). Measuring intangible effects of m-coupon campaigns on non-redeemers. Journal of Research in Interactive Marketing, 6 (3), pp.198-214.

Blundo, C., Cimato, S. \& De Bonis, A. (2005). Secure e-Coupons. Electronic Commerce Research, 5,pp.117-139

Business News Daily (2011). Digital coupons bring in new users, transform marketplace. Retrieved from: www.businessnewsdaily.com/881-digitalcoupons-redemption.html. [Accessed on: 30 January 2015].

Chen, M. F. \& Lu, T.Y. (2011). E-coupon proneness as a Mediator in the extended TPB model to predict consumers' usage intentions. Internet Research, 21 (5), pp. 508-526.

Cheng, H. \& Dogan, K.(2008). Customer-centric marketing with internet coupons. Kutsal Decision Support Systems, (44), pp.606-620.

Cheng, H.K., Dogan, K. \& Warner, E. (2005). Internet coupons: clicking not clipping. In: Department of Information Systems and Operations Management Working Paper.The University of Florida.

Chiou-Wei, S. \& Inman, J. (2008).Do shoppers like electronic coupons? A panel data analysis..Journal of Retailing, 84 (3), pp. 297-307.

Common Kindness (2012). Recent studies show online coupons gaining clout in brand marketing strategy. Retrieved from: 
http://www.prweb.com/releases/online-coupons/printablegrocery/prweb9660378.htm. [Accessed on: 15 January 2015].

Coupon Information Corporation (2014). Consumers. Retrieved from: http://www.couponinformationcenter.com/consideratecouponswebsite.php. [A ccessed on: 23 January 2015].

Dev, C., Falk, L. \& Stroock, L. (2011). To Groupon or not to Groupon: A tour operator's dilemma. Cornell Hospitality report, 11(19). New York: Cornell University.

DeVellis, R.F. (2003). Scale development: Theory and applications, $2^{\text {nd }}$ ed. Thousand Oaks, California: Sage.

Dholakia, U. \& Tsabar, G. (2011). A start up's experience with running a Groupon promotion. Retrieved from: http://ssrn.com/1828 003. [Accessed on:28January 2015].

Duncan, K. \&Mulpuru-Kodali, S. (2014). The state of digital coupons, how digital coupons are adapting to mobile and omnichannel. Forrester Consulting. Retrieved from:http://www.slideshare.net/RetailMeNotInc/thestate-of-digital-coupons. [ Accessed on: 11 January 2015].

Eblin J. (2015). How to obtain travel agent discounts. Demand Media.USA Today. Retrieved from: http://traveltips.usatoday.com/obtain-travel-agentdiscounts-1729.html.[ Accessed on: 22 February 2015].

E-Marketer (2013).Majority of US Internet Users Will Redeem Digital Coupons in 2013.Retrieved from: http://www.emarketer.com/Article/Majority-of-US-Internet-Users-WillRedeem-Digital-Coupons-2013/1010313\#sthash.1RrNpKyD.dpuf.

Accessed on: 23 February 2015].

E-Marketer (2014). US Mobile users turn to smart phones and tablets to redeem coupons. Retrieved from: http://www.emarketer.com/Article/USMobile-Users-Turn-Smartphones-Tablets-Redeem-Coupons/1010801.[

Accessed on: 28 January 2015].

E-Marketer (2017).Worldwide Digital Travel Sales: eMarketer's Estimates for 2016-2021; E-Marketer Report. Retrieved from: https://www.emarketer.com/Report/WorldwideDigital-Travel-Sales-eMarketers-Estimates-20162021/2002089. [Accessed on 11August 2017].

Euromonitor International (2016). Travel in Egypt; Country Report Exclusive Summary. Retrieved from: http://www.euromonitor.com/travel-inegypt/report.[Accessed on: 8 August 2017].

Faraj,M., Fadnis,C., Hoffman,C., Strachan, J., Kaddoura,S. \& Sileo, L. (2015). Middle East Online Travel Overview Second Edition. Retrieved from: http://www.phocuswright.com/Travel-Research/Market-OverviewSizing/Middle-East-Online-Travel-Overview-Second-Edition.[ Accessed on: 10 August 2017].

Forrester Consulting (2011). The impact of online coupons and promotion codes.

Forrester

Research,

Inc.

Retrieved 


\section{The use of electronic coupons in travel agencies: An exploratory study applied on Egyptian and US travel agents}

from:http://i.whalesharkmediacdn.com/site/pr/the-impact-of-online-couponsand-promotional-codes-sep2011.pdf. [Accessed on: 4 January 2015].

Forrester Consulting (2014). The state of digital coupons. Retrieved from: http://www.retailmenot.com/corp/webinars/?source=webinar. [Accessed on: 25 January 2015].

Georgieva, M. (2011). Should businesses use coupon-based services? Retrieved from: http://.hubspot.com/ tabid/6307/bid/16543/ShouldBusinesses-Use-Coupon-based-Services-Marketing-Cast.aspx. [Accessed on: 28 January 2015].

Hamlin, K. (2014). What are the benefits of using a travel agent?Demand Media. Retrieved from: http://traveltips.usatoday.com/benefits-using-travelagent-62907.html. [Accessed on: 15 February 2015].

Hockenson, L. (2012). The Evolution of Online Travel. Retrieved from: http://mashable.com/2012/02/21/online-travelinfographic/\#8n_PZ4qMDOqC. [Accessed on: 9 August 2017].

Hoffman, D.R., Ketcham, A. F. \& Taylor III, F. A. (1992). Electronic coupons: A double-barreled sales promotion technique. American Journal of Business, 7 (1), pp.42- 48.

Hopkins, J. (2011). Coupons: better with click or brick? Retrieved from: http:// hubspot.com/tabid/6307/bid/9575/Coupons-Better-with-Click-orBrick.asp. [Accessed on: 30 January 2015].

Jones, G. (2012). Studies Show Online Coupons Gaining Clout in Brand Marketing Strategy. Retrieved from: http://grahamjones.co.uk/2012/newswire/internet-marketing-news/recentstudies-show-online-coupons-gaining-clout-in-brand-marketing-strategy. html. [Accessed on: 4 February 2015].

Kang, H., Hahn, M., Fortin, D., Hyun, Y. \&Eom, Y.(2006). Effects of perceived behavioral control on the consumer usage intention of Ecoupons.Psychology \& Marketing,23(10), pp. 841-864.

Kimes, S. \& Dholakia, U. (2011). Restaurant daily deals: Customers' response to social couponing. NY: Cornell Hospitality, 11(20), pp.4-21.

Lai, H. \& Hsu, S.H. (2015). Intention to Repurchase Group Coupon Service: The Intertwined Effect of Service Quality of Vendor and Service Provider. In: B. Kamiński et al. (Eds.): GDN 2015, LNBIP 218, 321-332. DOI: 10.1007/978-3-319-19515-5_25.

Marketing Charts (2012). Coupons influence majority of consumers. Retrieved from: http://www.marketingcharts.com/traditional/couponsinfluence-majority-of-consumers -20795/. [Accessed on: 23 January 2015]. 
Marketing Charts (2014). 44\% say coupons very influential in brand choice. Retrieved from: http://www.marketingcharts.com/traditional/44-say-couponsvery-influential-in-brand-choice-41806/. [Accessed on: 24 February 2015].

McKenzie, R.B. \& Tullock, G. (2012). The New World of Economics, Springer, Verlag Berlin Heidelberg.

NCH Marketing Services (2009a). Coupons provide product movement, sales and advertising. Coupon Facts Report. Retrieved from: http://www.santella.com/ coupon.htm\# COUPONS PROVIDE PRODUCT MOVEMENT, SALES AND ADVERTISING. [Accessed on: 6 January 2015].

$\mathrm{NCH}$ Marketing Services (2009b).Couponing as a marketing strategy. Coupon Facts Report. NCH Marketing Services Inc.Retrieved from: http://www.santella.com/coupon.htm\#COUPONING AS A MARKETING STRATEGY. [Accessed on: 6 January 2015].

$\mathrm{NCH}$ Marketing Services (2014).Couponing enters the digital scene. Retrieved from: http://www.santella.com/coupon.htm\#COUPONING ENTERS THE DIGITAL SCENE. [Accessed on: 25 December 2014].

Nunnally, J. (1978). Psychometric theory, $1^{\text {st }}$ ed. New York: McGraw-Hill. Park, Y. \& Gretzel, U.(2011).Travel coupon proneness. Annals of Tourism Research, 38(4), pp.1653-1657.

PRNewswire (2013). A Coupon Nation: Americans Proudly Use Coupons More Than Shoppers in Great Britain, India and China, Among Others. Retrieved from: http://www.prnewswire.com/news-releases/a-coupon-nationamericans-proudly-use-coupons-more-than-shoppers-in-great-britain-indiaand-china-among-others-220485721.html. [Accessed on: 12 August 2017]. Rampell, A. (2008). How Coupons Boost Online sales; Case Study. Retrieved from: http://www.trialpay.com/2008/07/how-coupons-boostonline-sales-a-case-study/. [Accessed on: 28 December 2014].

Reichhart, P., Pescher, C. \& Spann, M. (2013).A comparison of the effectiveness of e-mail coupons and mobile text message coupons for digital products. Electron Markets, 23, pp.217-225.

Santella\& Associates (2013). Online coupons increase 111 percent to 242 million in 2002. Retrieved from:www.santella.com/coupon.htm. [Accessed on: 30 April 2015].

Sigala, M. (2013). A framework for designing and implementing effective online coupons in tourism and hospitality. Journal of Vacation Marketing, 19(2), pp.165-180.

Smith, K.T.(2011).Digital marketing strategies that Millennials find appealing, motivating, or just annoying. Journal of strategic Marketing, 19 (6),pp.489-499.

Watters, J. (2014). Why use a travel agent? Travel sense.org powered by ASTA. Retrieved from: http://www.travelsense.org/tips/whyuseanagent.cfm. [Accessed on: 2 January 2015]. 
The use of electronic coupons in travel agencies: An exploratory study applied on Egyptian and US travel agents

WhaleShark Media (2011). Research study shows online coupons drive incremental business and generate new users. Retrieved from: http://www.businesswire.com/news/ home/ 20111005005467/en/ResearchStudy-Shows-Online-Coupons-Drive-Incremental\#.VHjnQMstDIU.

[Accessed on: 5 January 2015].

Yim, J. (2015).Review of coupon systems.Advanced Science and Technology Letters, 117, pp.65-68.

Zhao, X., Liu, Y., Bi, H. \& Law, R. (2014).Influence of coupons on online travel reservation service recovery. Journal of Hospitality Journal of Hospitality and Tourism Management, 21, p.p. 18-26. 